\title{
COMPARISON BETWEEN WOOD DRYING DEFECT SCORES: SPECIMEN TESTING X ANALYSIS OF KILN-DRIED BOARDS ${ }^{1}$
}

\author{
Djeison Cesar Batista ${ }^{2}$, Márcio Pereira da Rocha ${ }^{3}$ e Ricardo Jorge Klitzke ${ }^{4}$
}

\begin{abstract}
It is important to develop drying technologies for Eucalyptus grandis lumber, which is one of the most planted species of this genus in Brazil and plays an important role as raw material for the wood industry. The general aim of this work was to assess the conventional kiln drying of juvenile wood of three clones of Eucalyptus grandis. The specific aims were to compare the behavior between: i) drying defects indicated by tests with wood specimens and conventional kiln-dried boards; and ii) physical properties and the drying quality. Five 11-year-old trees of each clone were felled, and only flatsawn boards of the first $\log$ were used. Basic density and total shrinkage were determined, and the drying test with wood specimens at $100{ }^{\circ} \mathrm{C}$ was carried out. Kiln drying of boards was performed, and initial and final moisture content, moisture gradient in thickness, drying stresses and drying defects were assessed. The defect scoring method was used to verify the behavior between the defects detected by specimen testing and the defects detected in kilndried boards. As main results, the drying schedule was too severe for the wood, resulting in a high level of boards with defects. The behavior between the defects in the drying test with specimens and the defects of kiln-dried boards was different, there was no correspondence, according to the defect scoring method.

Keywords: Eucalyptus grandis; Artificial drying; Drying quality.
\end{abstract}

\section{COMPARAÇÃO ENTRE ESCORES DE DEFEITOS DE SECAGEM DA MADEIRA: TESTE DE AMOSTRAS DE PEQUENAS DIMENSÕES X SECAGEM CONVENCIONAL DE TÁBUAS}

\begin{abstract}
RESUMO - É importante desenvolver tecnologias de secagem para a madeira de Eucalyptus grandis, que é uma das espécies mais plantadas do gênero no Brasil e desempenha papel significativo no abastecimento da indústria madeireira nacional. O objetivo geral deste trabalho foi avaliar a secagem convencional da madeira de três clones de Eucalyptus grandis. Os objetivos específicos foram comparar os comportamentos entre: i) os defeitos do ensaio de secagem de amostras de pequenas dimensões com os defeitos da secagem convencional de tábuas em câmara; e ii) as propriedades físicas e a qualidade da secagem. Foram coletadas cinco árvores de 11 anos de cada um dos clones de Eucalyptus grandis, utilizando-se apenas tábuas tangenciais da primeira tora. Foram determinadas a densidade básica e a contração total da madeira, bem como foi realizado o ensaio de secagem de amostras de pequenas dimensões a $100^{\circ} \mathrm{C}$. Procedeu-se à secagem convencional em câmarapiloto, em que foram avaliados as umidades inicial e final, o gradiente de umidade na espessura, as tensões residuais e os defeitos de secagem. Utilizou-se a metodologia de escore de defeitos para comparar o comportamento entre os defeitos do ensaio de amostras de pequenas dimensões e aqueles da secagem convencional. Destaca-se que o programa de secagem utilizado foi muito severo para a madeira analisada, resultando em grande quantidade de tábuas com defeitos. O comportamento entre os defeitos do ensaio de amostras de pequenas dimensões e os defeitos de tábuas na secagem convencional foi diferente, não havendo correspondência.
\end{abstract}

Palavras-chave: Eucalyptus grandis; Secagem artificial; Qualidade da secagem.

\footnotetext{
${ }^{1}$ Recebido em 29.05.2014 aceito para publicação em 26.11.2014.

${ }^{2}$ Universidade Federal do Espírito Santo, Centro de Ciências Agrárias, Departamento de Ciências Florestais e da Madeira, Jerônimo Monteiro, Espírito Santo - Brasil. E-mail: <djeison.batista@ufes.br>.

${ }^{3}$ Universidade Federal do Paraná, Setor de Ciências Agrárias, Departamento de Engenharia e Tecnologia Florestal, Curitiba, Paraná - Brasil. E-mail: <mprocha@ufpr.br>.

${ }^{4}$ Universidade Federal do Paraná, Setor de Ciências Agrárias, Departamento de Engenharia e Tecnologia Florestal, Curitiba, PR - Brasil. E-mail: <rjkklitzke@gmail.com>.
}

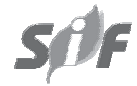

Revista Árvore, Viçosa-MG, v.39, n.2, p.395-403, 2015

http://dx.doi.org/10.1590/0100-67622015000200019 


\section{INTRODUCTION}

Eucalyptus species play a fundamental role as raw material for the Brazilian wood industry, mostly pulp and paper mills. For use as lumber in higher added value products, it is important to develop proper drying technologies, particularly for Eucalyptus grandis wood, which is one of the most planted species of this genus in Brazil.

The drying quality and behavior of a species is associated with its wood anatomy, and Eucalyptus grandis has vessel elements with small diameters and/ or obstructed by tylosis (ALFONSO, 1987). Both factors hinder. These characteristics, associated with the high shrinkage (GONÇALEZ et al., 2006; SILVA et al., 2006), make this species very prone to drying defects, such as collapse, checks and warping.

Some Brazilian researchers (ANDRADE et al., 2001; BARBOSA et al., 2005; BRANDÃO, 1989; CINIGLIO, 1998) have used the method of Terazawa (1965) to develop drying schedules for kiln drying. Terazawa's method consists of drying wood specimens at $100^{\circ} \mathrm{C}$ in a laboratory oven to measure different drying rates and some levels of defects, which are used in statistical models to determine initial and final dry and wet bulb temperatures and the drying gradient. These are the main parameters in the development of drying schedules. The method also assumes that the drying quality (regarding drying defects) of the specimens (laboratory test) will be directly related to those found in industrial scale kiln drying.

The following research problems are assessed in this paper: i) Was the drying schedule used proper for kiln drying of juvenile wood of Eucalyptus grandis?; ii) Is there some relation between the drying defects of wood specimens (Terazawa's method) and the drying defects of kiln dried boards?; iii) What are the effects of wood density and shrinkage on drying quality?

To answer these questions, we formulated the following hypotheses: i) The drying schedule used is proper; ii) There is a direct relation between the defects of wood specimens and boards, meaning they have the same behavior; iii) Density and shrinkage have significant effects on drying quality, where less dense and more stable wood has better drying quality.

The general aim of this work was to assess the conventional kiln drying of juvenile wood of three clones of Eucalyptus grandis. The specific aims were to compare the behavior between: i) drying defects of wood specimens and drying defects of kiln-dried boards; ii) physical properties and drying quality.

\section{MATERIALAND METHODS}

\subsection{Material and sampling}

Three clones of Eucalyptus grandis W. Hill ex Maiden were assessed, which were selected according to the volumetric production criterion, where clone 1 was the least productive, clone 2 was intermediate and clone 3 was the most productive. Five trees of each clone were felled from an 11-year-old planted stand in the town of Telêmaco Borba, Paraná, Brazil. The trees presented diameter at breast-height greater than $200 \mathrm{~mm}$, straight trunks and apparently no plant diseases. Only the first logs $(3,000 \mathrm{~mm})$ were used and broken down into flatsawn boards ( $30 \times 150-200 \times 3,000 \mathrm{~mm})$, and just four boards per log were used, from the mean position of the logs' rays between the pith and the bark. After breakdown, the boards were trimmed to $745 \mathrm{~mm}$ length, the maximum width supported by the pilot-scale kiln.

\subsection{Physical properties}

Total shrinkage was assessed according to the COPANT 462 (1972) standard and basic density was assessed by direct measurement with the same specimens, where $50(25 \times 25 \times 100 \mathrm{~mm})$ were used for each clone.

\subsection{Drying test with wood specimens}

According to Terazawa (1965), wood specimens of small dimension, when submitted to drastic drying in laboratory equipment, will present proportional defects to those of industrial kiln-dried boards.

Ten specimens $(30 \times 150-200 \times 250 \mathrm{~mm})$ per clone were used in this test, which were previously top-sealed with polyvinyl acetate and weighed (initial mass) with a semi-analytical balance $(0.01 \mathrm{~g})$. The specimens were then put in a laboratory oven at $100{ }^{\circ} \mathrm{C}$ for $120 \mathrm{~h}$, the time needed to reach about $5 \%$ final moisture content. The method of moisture content determination and monitoring until final moisture content was that described by Galvão and Jankowsky (1985).

At the end of the test, the specimens were assessed regarding checks (end, surface and internal) and collapse, considering the worst defects, with use of a digital

Revista Árvore, Viçosa-MG, v.39, n.2, p.395-403, 2015

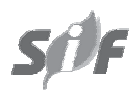


caliper $(0.01 \mathrm{~mm})$. Surface checks were assessed regarding length (grain direction) and width (tangential direction); and internal checks were assessed regarding height (radial direction) and width (tangential direction). For internal checks, the specimens were crosscut into three equal parts, producing four transversal faces for evaluation. Finally, collapse was assessed on the same four faces considering the smallest thickness. The measurements of the different defects were transformed into scores, according to the method of Brandão (1989), where less severe defects mean smaller scores. The different scores of the four different defects were summed, resulting in only one score per specimen in this test.

\subsection{Conventional kiln drying}

Wood was kiln dried in a pilot scale ( $4 \mathrm{~m}^{3}$ capacity) conventional temperature kiln. The heating system is composed of electric resistances, and the circulation system is composed of a single fan that blows air at a speed of $2 \mathrm{~m} . \mathrm{s}^{-1}$ across the stack transversally to board length (stack width). Venting and humidification systems are composed of two dampers and a steam spray line, provided with low pressure steam by an electric boiler. The drying conditions were controlled by automatic equipment, connected to a personal computer with specific software. Kiln stack moisture content was controlled automatically by eight pairs of electric resistive sensors.

A single stack was prepared per kiln batch (three in total), of $500 \times 745 \times 1,200 \mathrm{~mm}$, respectively for height, width and length, composed of 81 boards, 27 per clone. The boards of different clones were randomly spread in the stack and dried together for equal evaluation of the quality. The stickers were $25 \mathrm{~mm}$ (square section) and 1,500 $\mathrm{mm}$ long. Prior to stacking and trimming the boards, six specimens per clone were taken in order to determine initial moisture content (gravimetric method). The drying schedule used in the three batches is presented in Table 1.

\subsection{Assessing kiln drying quality}

Kiln drying quality was assessed regarding defect occurrence, final moisture content, moisture gradient in thickness and drying stresses, which were evaluated $24 \mathrm{~h}$ after the end of the cooling phase of each batch, according to the recommendations of Galvão and Jankowsky (1985) and Simpson (1991).

\subsubsection{Drying defects}

The drying defects assessed were checks (end and surface), cupping and collapse, based on the criterion of "present" or "absent", where nine boards per clone per batch were used, resulting in 27 boards for each clone.

\subsubsection{Final moisture content, moisture gradient in thickness and drying stresses}

Three boards per clone per batch were assessed, resulting in nine boards for each clone. Each board was trimmed to produce three specimens (A, B and C) of $25 \mathrm{~mm}$ length (along the grain).

Specimens A were used to determine the final moisture content and specimens B were used to determine the moisture gradient in thickness, both by the gravimetric method, while specimens $\mathrm{C}$ were used to assess drying stresses, according to the prong test, where specimens were classified as: casehardened (stressed), notcasehardened (free of stresses) and reverse casehardened (reverse stresses).

\subsection{Statistical analysis}

The statistical analysis was performed using a trial version of the Statgraphics Centurion XVI.II software, according to a completely randomized design, where each clone represented a treatment, with $95 \%$ confidence level for all tests.

\subsubsection{Discrete data}

Discrete data were analyzed by the Kruskal-Wallis test, which provides a nonparametric method for analysis of variance (ANOVA), for classification of a criterion or experiments with one factor, where generalizations can be done (SPIEGEL, 1994). In this test, the original data of all treatments are ranked in increasing order and receive scores, giving an average score per treatment instead of an overall average. Where at least one median was not statistically equal ( $\mathrm{P}$-value $<0.05$ ), box-andwhisker plots were used to identify which medians were different from each other.

For the drying test with wood specimens, each specimen received a score for each of the four kinds of defects assessed, which were summed to result in just one score per specimen. This test had 10 repetitions per clone. For kiln drying, the boards were counted for each of the four kinds of defects assessed by batch.

Revista Árvore, Viçosa-MG, v.39, n.2, p.395-403, 2015 
Boards with the same defect in the three batches were summed, resulting in a general count. Thus, the analysis of each clone regarded four counts or repetitions, represented by the four defect types.

\subsubsection{Continuous data}

The differences of the clones regarding basic density, total shrinkage, initial and final moisture content, and moisture gradient in thickness were checked by applying analysis of variance (ANOVA). In cases where there was statistically significant influence of the clone $(\mathrm{P}$-value $<0.05)$, the Tukey multiple range test was applied to determine which averages were different from each other.

\section{RESULTS}

\subsection{Physical properties}

Table 2 presents the results of the physical properties of the wood of Eucalyptus grandis clones.

\subsection{Defect scores from the drying test with wood specimens}

The averages of the scores from the drying test with wood specimens were 14.6, 10.1 and 21.8, respectively for clones 1,2 and 3 , and according to Kruskal-Wallis test $(\mathrm{Hc}=9.11, \mathrm{P}$-value $=0.01048)$ there was a statistically significant difference between the medians of the clones' scores. Figure 1 presents the box-and-whisker plots used to identify which medians were different from each other.

\subsection{Assessment of kiln drying quality}

\subsubsection{Batches}

The batches' cycles lasted 453 hours on average. The averages (with coefficient of variation in parentheses) of initial moisture content of wood of clones 1, 2 and 3 were respectively $87.3 \%(20.2 \%), 59.4 \%(27.6 \%)$ and $85.9 \%$ (12.2\%). Eighteen specimens per clone were

Table 1 - Drying schedule.

Tabela 1 - Programa de secagem.

\begin{tabular}{|c|c|c|c|c|c|c|}
\hline \multirow[b]{2}{*}{$\begin{array}{c}\text { Moisture content } \\
(\%)\end{array}$} & \multicolumn{2}{|c|}{ Temperature $\left({ }^{\circ} \mathrm{C}\right)$} & \multirow[b]{2}{*}{$\begin{array}{c}\text { Relative } \\
\text { humidity (\%) }\end{array}$} & \multirow[b]{2}{*}{$\begin{array}{c}\text { Equilibrium moisture } \\
\text { content }(\%)\end{array}$} & \multirow[b]{2}{*}{$\begin{array}{l}\text { Time } \\
(\mathrm{h})\end{array}$} & \multirow[b]{2}{*}{$\begin{array}{l}\text { Drying } \\
\text { gradient }\end{array}$} \\
\hline & $\begin{array}{l}\text { Dry bulb } \\
\quad\left({ }^{\circ} \mathrm{C}\right)\end{array}$ & $\begin{array}{l}\text { Wet bulb } \\
(\%)\end{array}$ & & & & \\
\hline Warming & 40 & 39 & 94 & - & 3 & - \\
\hline 45 & 40 & 38 & 88 & 18 & $*$ & 2.5 \\
\hline 35 & 44 & 41 & 84 & 16 & $*$ & 2.2 \\
\hline 31 & 46 & 42 & 78 & 14 & $*$ & 2.2 \\
\hline 28 & 50 & 45 & 77 & 14 & $*$ & 2.0 \\
\hline 25 & 54 & 48 & 71 & 12 & $*$ & 2.1 \\
\hline 20 & 58 & 49 & 64 & 10 & * & 2.0 \\
\hline 17 & 60 & 49 & 55 & 8 & * & 2.1 \\
\hline 15 & 62 & 49 & 48 & 7 & $*$ & 2.1 \\
\hline 12 & 66 & 51 & 46 & 6 & * & 2.0 \\
\hline 10 & 66 & 47 & 35 & 5 & * & 2.0 \\
\hline Equalizing -10 & 64 & 56 & 66 & 10 & 8 & - \\
\hline Conditioning -10 & 62 & 56 & 73 & 12 & 8 & - \\
\hline Cooling -10 & 44 & 35 & 55 & 9 & 4 & - \\
\hline
\end{tabular}

*Not time-controlled.

Table 2 - Averages of basic density and total shrinkage of juvenile wood of Eucalyptus grandis clones.

Tabela 2 - Médias de densidade básica e contração total da madeira juvenil dos clones de Eucalyptus grandis.

\begin{tabular}{|c|c|c|c|c|c|}
\hline Clone & $\begin{array}{l}\text { Basic density } \\
\left(\mathrm{g} . \mathrm{cm}^{-3}\right)\end{array}$ & $\begin{array}{c}\text { Coefficient of } \\
\text { shrinkage anisotropy }\end{array}$ & \multicolumn{3}{|c|}{ Total shrinkage (\%) } \\
\hline & & & Radial & Tangential & Volumetric \\
\hline 1 & $0.40 \mathrm{c}(7.5)$ & $1.95 \mathrm{~b}(10.3)$ & $4.37 \mathrm{a}(10.1)$ & $8.48 \mathrm{~b}(10.0)$ & $13.07 \mathrm{~b}(8.8)$ \\
\hline 2 & $0.45 \mathrm{~b}(8.3)$ & $1.90 \mathrm{~b}(13.3)$ & $4.67 \mathrm{a}(16.5)$ & $8.74 \mathrm{~b}(11.4)$ & $13.65 \mathrm{~b}(11.9)$ \\
\hline 3 & $0.48 \mathrm{a}(13.9)$ & $2.25 \mathrm{a}(21.4)$ & $4.65 \mathrm{a}(18.9)$ & $10.15 \mathrm{a}(11.4)$ & $15.06 \mathrm{a}(10.0)$ \\
\hline
\end{tabular}

$\mathrm{N}=50$. Numbers in parentheses correspond to the coefficient of variation (\%). Averages followed by the same letter, at least one, in a same column do not differ statistically at a level of $5 \%$ probability by the Tukey test.

Revista Árvore, Viçosa-MG, v.39, n.2, p.395-403, 2015 
assessed for initial moisture content. According to ANOVA $(\mathrm{Fc}=129.06, \mathrm{P}$-value $=0.00001)$, there was a statistically significant difference of the averages, where clone 2 had the smallest average and clones 1 and 3 did not differ significantly.

The averages (with coefficient of variation in parentheses) of final moisture content of clones 1, 2 and 3 were respectively $9.9 \%(11.3 \%), 9.6 \%(5.7 \%)$ and $10.4 \%(12.5 \%)$. Nine specimens per clone were assessed for final moisture content. According to ANOVA (Fc $=1.19, \mathrm{P}$-value $=0.33)$, there was no statistically significant difference of the averages.

\subsubsection{Moisture gradient in thickness and drying stresses}

According to the method applied, moisture gradient in thickness is represented by two values (1 and 2), one for each shell or layer, and are expressed in percentage points (p.p.). Nine specimens per clone were assessed in these tests. The averages of moisture gradient 1 (with coefficient of variation in parentheses) were 0.16 p.p. (12.2\%), 0.59 p.p. (7.1\%) and 1.18 p.p. (10.2\%) respectively for clones 1,2 and 3. According to ANOVA $(\mathrm{Fc}=36.78, \mathrm{P}$-value $=0.00001)$ and the Tukey test, all averages were statistically different from each other.

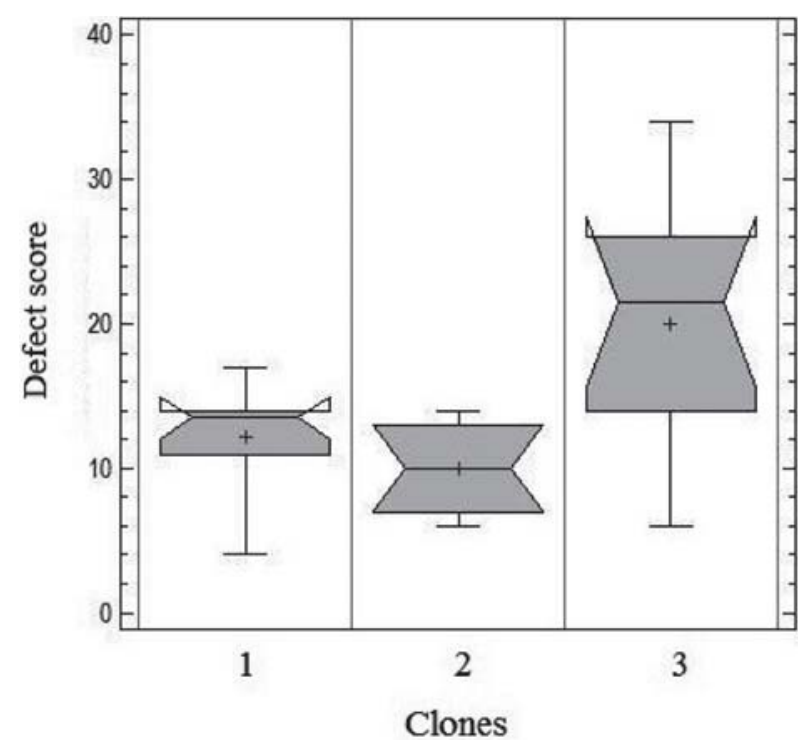

Figure 1 - Defect score of drying test with wood specimens. Figura 1 - Escore de defeitos do ensaio de secagem com amostras de pequenas dimensões.
The averages of moisture gradient 2 (with coefficient of variation in parentheses) were 0.13 p.p. (11.6\%), 0.55 p.p. (17.9\%) and 0.98 p.p. (14.7\%) respectively for clones 1, 2 and 3. According to ANOVA $(\mathrm{Fc}=19.36$, $\mathrm{P}$-value $=0.00001)$ and the Tukey test, all averages were statistically different from each other.

No specimens in the prong test presented reverse casehardening, so we analyzed a new qualitative classification of drying stresses: soft (the prongs do not touch each other), strong (the prongs touch) and not-casehardened (free of drying stresses). Nine specimens per clone were used in this assessment.

Regarding soft casehardening, the percentages of specimens were $88.9 \%, 100.0 \%$ and $55.6 \%$; strong casehardening: $0.0 \%, 0.0 \%$ and $44.4 \%$; not-casehardened: $11.1 \%, 0.0 \%$ and $0.0 \%$, all respectively for clones 1,2 and 3 . No statistical analysis was performed for these data.

\subsubsection{Drying defects}

Figure 2 presents the percentage of boards with kiln drying defects, where twenty-seven boards were assessed for each clone. No board presented surface checks, so this is not shown in Figure 2. However, this does not mean the boards were free of surface checks, because this kind of defect in hardwood species can close in the end phases of the drying schedule (SIMPSON, 1991), mostly in equalized and conditioned batches.

\subsection{Comparison of scores}

The count of kiln dried boards with defects, by kind of defect, resulted in the following average scores:

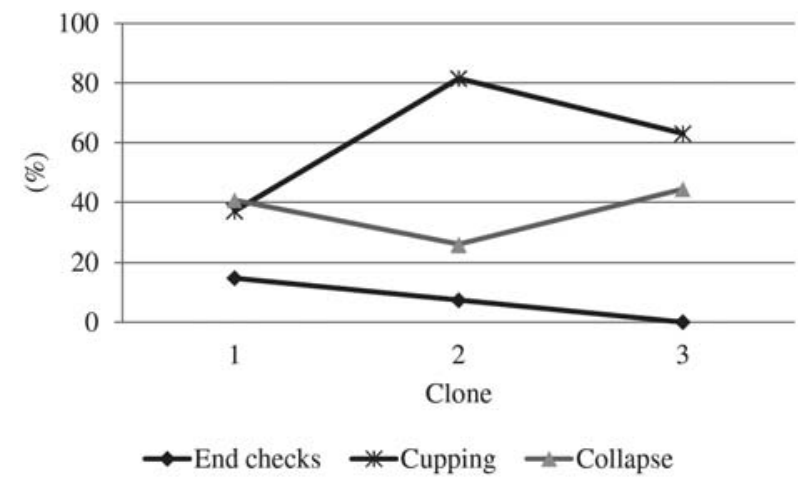

Figure 2 - Percentage of boards with drying defects for each clone of Eucalyptus grandis.

Figura 2 - Porcentagem de tábuas com defeitos de secagem por clone de Eucalyptus grandis.

Revista Árvore, Viçosa-MG, v.39, n.2, p.395-403, 2015

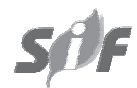


$6.5,6.6$ and 6.4 , respectively for clones 1,2 and 3 . According to the Kruskal-Wallis test $(\mathrm{Hc}=0.01, \mathrm{P}-$ value $=0.99)$, there was no significant difference among the medians of the number of boards with defects among the clones. Figure 3 shows a graphic with the results of clone defect scores: drying test with wood specimens and kiln-dried boards.

\section{DISCUSSION}

\subsection{Physical properties}

The basic density was significantly different among clones. Density is one of the most important properties of wood because it has a direct relation with many other properties, and is a useful parameter of wood drying behavior because it is an indication of permeability. Water should flow more easily through the wood of clone 1 than the other clones, because it is less dense.

The same way as density, total shrinkage is a good parameter for wood drying behavior because more stable wood is less prone to some kinds of drying defects, such as checks and warping. Based on the analysis of the volumetric shrinkage and the coefficient of anisotropy, clone 3 was the most dimensionally unstable, and clones 1 and 2 did not present significant differences between them.

Analyzing the physical properties presented in Table 2, clone 3 is expected to be more difficult to dry, meaning longer drying cycles, wider moisture gradient in thickness and higher frequency of defects than clones 1 and 2 .

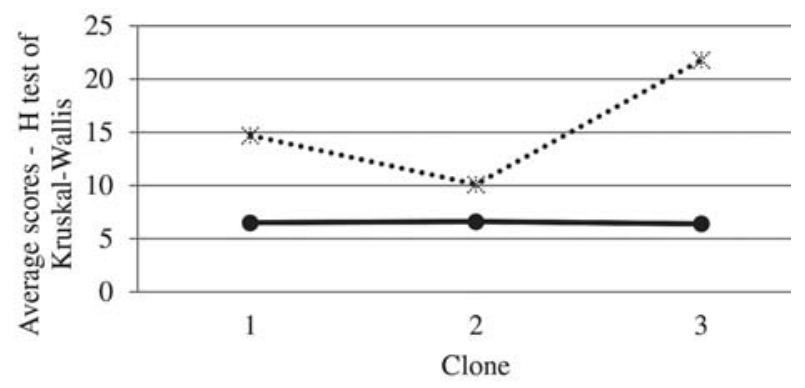

..... Drying test with wood specimens

$\rightarrow$ Conventional kiln dryng

Figure 3 -Comparison of defect scores: drying test with wood specimens and conventional kiln-dried boards.

Figura 3 - Comparação de escores de defeitos: amostras de pequenas dimensões e secagem convencional.

\subsection{Score of defects of the drying test with wood specimens}

Two dotted lines can be seen in Figure 1, which delimits the notches of clone 1's box-plot. They do not overlap the notches of the other clones' box-plots completely, meaning that the medians of the score of defects were mutually different. Thus, clone 2 presented fewer defects than clone 1 , and clone 3 had more defects in this test.

According to what was discussed before, clone 3 's wood was denser and more instable, resulting in more defects. Analyzing these results together, we can also expect clone 3 to have higher frequency of defects in kiln-dried boards. Clone 2's wood had intermediate density and was not statistically different from clone 1 regarding shrinkage, but it had the smallest defect score, followed by clone 1 . Analyzing these results, we can expect clones 1 and 2 to have lower frequency of defects in kiln-dried boards.

\subsection{Assessment of kiln-dried boards}

\subsubsection{Batches}

The initial moisture content of the wood samples was heterogeneous, which is not ideal regarding batch composition for drying. Clone 2 had less moisture content than clones 1 and 3. However, it was possible to reach homogeneity at the end of the drying cycle, as indicated by the relatively uniform final moisture content of the three clones, whose averages did not differ significantly. Regarding the control of final moisture content, the average of the clones was close to that pre-established in the drying schedule $(10 \%)$, so the result can be considered satisfactory.

The homogeneity of final moisture content does not permit any inference about the permeability of the wood because the drying schedule had equalizing and conditioning phases (Table 1). But the good results achieved indicate that the variables of the schedule and the time spent for equalization were satisfactory for the three clones.

\subsubsection{Moisture gradient in thickness and drying stresses}

The behavior of moisture gradients in thickness 1 and 2 was exactly the same, where clone 1 presented more homogeneous boards regarding inside (core) and

Revista Árvore, Viçosa-MG, v.39, n.2, p.395-403, 2015 
outside (shell) moisture contents than clones 2 and 3 , and the averages of all clones were statistically different from each other.

Moisture gradients of clone 1 were smaller than those reported by Mellado (1993) for boards of the same thickness $(30 \mathrm{~mm})$ and species, and the gradients of clone 2 were similar to that reported by the author, who obtained an average of 0.60 p.p. The averages of all clones were smaller than those noted by Ciniglio (1998), who obtained 2.0 p.p. and 4.0 p.p. respectively for Eucalyptus urophylla and Eucalyptus grandis woods. Even for clone 3, which had the highest moisture gradient (1.18 p.p.), this result can be considered good regarding conventional kiln drying, meaning that the time spent in the equalization phase of the drying schedule was satisfactory. The moisture gradient had exactly the same behavior as basic density, where the densest wood (clone 3 ) had the highest gradients.

We noticed a good relation between moisture gradient and drying stresses, which was expected since the latter is a consequence of the former (SIMPSON, 1991). For example, clone 1 had the smallest moisture gradients and was the only clone with non-casehardened boards and no boards with strong casehardening. On the other hand, clone 3 had the highest moisture gradients and no non-casehardened boards. It was also the only clone having boards with strong casehardening and had the fewest boards with soft casehardening. The results of clone 2 were intermediate, with $100 \%$ of boards presenting soft casehardening.

\subsubsection{Kiln drying defects}

End checks were more frequent in clone 1's boards (14.8\%), followed by clone $2(7.4 \%)$ and clone $3(0 \%)$. This kind of defect is associated with fragile tissues of pith and radial parenchyma, but the first explanation can be discarded because the boards sampled did not have that kind of tissue. Eucalyptus grandis wood has low amounts of parenchyma tissue (both radial and axial) and its rays are classified as thin to extremely thin, with thickness of 8 to $22 \mu \mathrm{m}$ (ALFONSO, 1987).

As the water flow is faster in the axial than transversal direction, the ends of the boards dry faster than the inner parts, causing drying stresses in those regions. This fact, associated with the fragile ray parenchyma tissue, might have led clone 1 's wood to have a higher percentage of end checked boards. Another assumption can be made regarding density, where clone 1 presented the smallest, represented by a less mechanically resistant tissue, which was not strong enough to resist the drying stresses, contributing to the appearance of end checks.

Cupping and collapse were more severe defects, meaning that higher percentages of boards with these defects were observed. Cupping is mainly caused by the difference in shrinkage between radial and tangential directions (SIMPSON, 1991), which can be expressed by the coefficient of shrinkage anisotropy (Table 2). Based on this coefficient, we expected clone 1's wood to have the smallest frequency of cupped boards, followed by clones 2 and 3, which was true only for clones 1 and 3 , with averages of that coefficient of 1.95 and 2.25 , respectively. However, clone 2's wood had the highest frequency of cupped boards $(81.5 \%)$, despite having a smaller coefficient (1.90) than clone 3 .

We suppose that clone 2's wood might have both higher grain deviation and growing stresses than the other clones, which are also factors associated with cupping (SIMPSON, 1991). Since cupping is a very harmful defect regarding wood quality and use, even for clone 1 the frequency or cupped boards can be considered too high.

For collapse, clone 2's wood presented the smallest frequency of boards with that defect, and clones 1 and 3 had similar frequencies, with respectively $40.7 \%$ and $44.4 \%$. Eucalyptus grandis wood is naturally prone to collapse because of its small cell dimensions, vessel element diameters and pit sizes, as well as high tylosis (ALFONSO, 1987). All of these factors diminish its permeability, causing high capillary tension stresses, which are the main cause of collapse during the flow of free water in wood (MELO, 1999).

Besides the anatomical features mentioned above, less dense woods (with fragile cell walls), as clone 1 $\left(0.40 \mathrm{~g} . \mathrm{cm}^{-3}\right)$, are more prone to collapse because of the low resistance to perpendicular compression, which is a kind of resistance required during the flow of free water in wood. Denser woods, as clone $3\left(0.48 \mathrm{~g} . \mathrm{cm}^{-3}\right)$, are more resistant but less permeable, causing higher capillary tension stresses. Clone's 2 wood had intermediate density $\left(0.45 \mathrm{~g} . \mathrm{cm}^{-3}\right)$, and had a better balance between mechanical resistance and permeability, leading to fewer boards with collapse (25.9\%). However, since collapse is a very harmful defect, causing great

Revista Árvore, Viçosa-MG, v.39, n.2, p.395-403, 2015 
loss of board volume and low quality classification, even for clone 2 the number of collapsed boards can be considered too high.

There was no clear relation among the clones regarding drying defects, because for each kind of defect assessed, a different clone presented better results than the others.

\subsection{Comparison of scores}

As can be seen in Figure 3, the defect scores of the different methods did not present the same behavior, which was not expected. Thus, it was not possible to attain the same behavior for the defect scores in the drying test with wood specimens and in the conventional kiln drying of boards.

\section{CONCLUSIONS}

Regarding the assessment of kiln drying of wood of Eucalyptus grandis clones:

- The equalization phase of the drying schedule was satisfactory because the final moisture content reached the pre-established level (10\%) and also because moisture gradient in thickness was small, where 1.18 p.p. was the highest average (clone 3 ).

- The conditioning phase of the drying schedule was not satisfactory because only a small percentage of boards of clone 1 (11\%) were non-casehardened at the end of the cycle.

- The conditions set up in the drying schedule were considered too severe for Eucalyptus grandis juvenile wood, because of the high percentage of boards with collapse and cupping, which are defects that diminish wood quality and limit its use as lumber.

- Cupping was the most frequent drying defect, while no boards presented surface checks.

- Despite the different wood densities of the clones, which is a criterion to select wood to compose a kiln batch, the wood of the three clones can be kiln dried together, with improvements in the drying schedule.

Regarding the specific goals:

- The behavior between the defects of the wood in the drying test with specimens and the defects of kiln-dried boards was different, according to the defect scoring method.

Revista Árvore, Viçosa-MG, v.39, n.2, p.395-403, 2015
- Denser and more unstable wood presented more defects in the drying test with wood specimens.

- Moisture gradient in thickness and drying stresses corresponded to basic density, where denser woods had higher moisture gradients and higher drying stresses.

- The relation between basic density and end checks was inverse, where less dense woods had higher frequency of this defect.

- It was not possible to establish any relation either between basic density and collapse or basic density and cupping. The same was true for total shrinkage and the entire kiln drying defects.

\section{ACKNOWLEDGEMENTS}

The first author would like to thank: the Brazilian Government through CNPq - Conselho Nacional de Desenvolvimento Científico e Tecnológico (National Counsel of Technological and Scientific Development) for the research grant; the Klabin Company, which donated the wood.

\section{REFERENCES}

ALFONSO, V.A. Caracterização anatômica do lenho e da casca das principais espécies de Eucalyptus L'Hérit. cultivadas no Brasil. 1987. 188f. Tese (Doutorado em Ciências) - Universidade de São Paulo, São Paulo, 1987.

ANDRADE, A.; JANKOWSKY, I.P.; DUCATTI, M.A. Grupamento de madeiras para secagem convencional. Scientia Forestalis, n. 59, p. 89-99, 2001.

BARBOSA, C.G.; LIMA, J.T.; ROSADO, S.C.C.; TRUGILHO, P.F. Elaboração de programa de secagem para madeiras de clones de híbridos de Eucalyptus spp. Cerne, v. 11, n. 1, p. 40-48, jan.mar. 2005.

BRANDÃO, A.T.O. Determinação de metodologia para a indicação de programas de secagem de madeiras. 1989. 100f. Dissertação (Mestrado em Ciências Florestais) - Escola Superior de Agricultura Luiz de Queiroz, Universidade de São Paulo, Piracicaba, 1989. 
CINIGLiO, G. Avaliação da secagem de madeira serrada de $E$. grandis e $E$. urophylla. 1998. 73f. Dissertação (Mestrado em Ciências e Tecnologia de Madeiras) - Escola Superior de Agricultura Luiz de Queiroz, Universidade de São Paulo, Piracicaba, 1998.

COMISSIÓN PANAMERICANA DE NORMAS

TÉCNICAS - COPANT 462 - Método de determinación de la contracción. Buenos Aires: 1972.

GALVÃO, A. P.M.; JANKOWSKY, I.P. Secagem racional da madeira. São Paulo: Nobel, 1985.

GONÇALEZ, J.C.; BREDA, L.C.S.; BARROS, J.F.M.; MACEDO, D.G.; JANIN, G.; COSTA, A.F.; VALE, A.T. Características tecnológicas das madeiras de Eucalyptus grandis W.Hill ex Maiden e Eucalyptus cloeziana F. Muell visando ao seu aproveitamento na indústria moveleira. Ciência Florestal, v. 16, n. 3, p. 329-341. 2006.

MELLADO, E.C.E.R. Contribuição ao desenvolvimento tecnológico para a utilização de madeira serrada de
Eucalyptus grandis (Hill ex Maiden) na geração de produtos com maior valor agregado. 1993. 133f. Dissertação (Mestrado em Ciências Florestais) - Setor de Ciências Agrárias, Universidade Federal do Paraná, Curitiba, 1993.

MELO, J.R. Secagem de madeiras: teoria e prática de secagem de madeiras. Lisboa: Estação Florestal Nacional, 1999.

SILVA, J. C.; OLIVEIRA, J.T.S.; XAVIER, B.A.; CASTRO, V.R. Variação da retratibilidade da madeira de Eucalyptus grandis Hill ex Maiden, em função da idade e da posição radial no tronco. Revista Árvore, v.30, n.5, p.803-810, 2006.

SIMPSON, W.T. Dry kiln operator's manual. Madison: USDA/FS/FPL, 1991.

SPIEGEL, M.R. Estatística. $3^{\text {rd }}$ ed. São Paulo: Pearson Education do Brasil, 1994.

TERAZAWA, S. Methods for easy determination of kiln drying schedule of wood. Japan Wood Industry, v.20, n.5, p.216-226, 1965. 